\title{
Uji Sensitisasi Dermal Masker Gel Kombinasi Ekstrak Ampas Daun Teh dan Air Cucian Beras
}

\author{
Dermal Sensitization Test of Gel Mask Containing Combination of Green Tea Waste \\ Extract and Rice Washing Water
}

\author{
Andi Nurul Annisa*, Wahyu Utaminingrum, Erza Genatrika \\ Ilmu Farmasi, Fakultas Farmasi, Universitas Muhammadiyah Purwokerto, Purwokerto, Indonesia \\ *E-mail: andinurulanis@gmail.com
}

\begin{abstract}
Abstrak
Kombinasi ekstrak ampas daun teh dan air cucian beras sebagai masker gel peel-off diketahui stabil dalam penyimpanan 28 hari dan memiliki nilai $\mathrm{IC}_{50}$ sebesar 20,4 ppm. Potensi tersebut dapat memberikan efek optimal sebagai bahan kosmetika.Akan tetapi, untuk memenuhi persyaratan regulasi Badan Pengawas Obat Makanan (BPOM) RI dan ISO 10993, uji sensitisasi kulit juga harus dilakukan. Penelitian ini bertujuan untuk mengetahui reaksi sensitisasi kulit dari masker gel peel-off yang mengandung kombinasi ekstrak ampas daun teh (Camellia sinensis L.) dan air cucian beras (Oryza sativa L.) pada hewan uji. Desain penelitian menggunakan eksperimental laboratorium dan pemilihan sampel secara simple random sampling. Perlakuan diberikan berdasarkan posttest-only control group design. Hasil uji reaksi sensitisasi kulit ditentukan menggunakan metode Guinea Pig Maximization Test (GPMT). Hasil penelitian menunjukkan adanya reaksi eritema maupun edema menurut Skala Magnusson dan Kligman setelah pemberian masker gel peel-off sebagai sampel dalam uji topikal pada hewan uji muncul pada hari ke-11 dan pada uji tantang baru muncul pada hari ke-24. Hal ini disebabkan masa inkubasi selama 1 minggu dimana keadaan hipersensitivitas dapat berkembang sehingga reaksi tersebut disebut juga dengan reaksi hipersensitivitas tertunda.
\end{abstract}

Kata kunci: Masker gel; Ampas daun teh; Air cucian beras; Uji sensitisasi

\begin{abstract}
The combination of tea leaf dregs extract and rice washing water as a peel-off gel mask was found to be stable up to 28 days of storage and had an IC50 value 20.4 ppm. This potential can provide an optimal effects as cosmetic ingredients. However, to meet the regulatory requirements of Badan Pengawas Obat Makanan (BPOM) RI and ISO 10993, a dermal sensitization test also need to be done. The aim of this study was to determine the dermal sensitization reaction from peel-off gel mask containing a combination of tea leaf dregsextract (Camellia sinensis L.) and rice washing water (Oryza sativa L.) in test animal. Thisstudy was designed based on experimental laboratory methods and sample selection by simple random sampling. The intervention was given based on posttest-only control group design. The test results for dermal sensitization were determined using the Guinea Pig Maximization Test (GPMT) method. The results showed erythema and edema reactions according to the Magnusson and Kligman scale after administration of peel-off gel masks as samples in the topical tests in test animals, appeared on the $11^{\text {th }}$ day and in the challenge test appeared on the 24th day. This was due to incubation period for one week where the hypersensitivity state can develop, so that this reaction is also called the delayed hypersensitivity reaction.
\end{abstract}

Keywords: Gel mask; Green tea waste; Rice washing water; Sensitization test 


\section{PENDAHULUAN}

Teh dan beras merupakan bahan yang secara empiris digunakan untuk perawatan kecantikan sebagai warisan tradisional di Indonesia. Disisi lain, penggunaan teh dan beras lebih banyak digunakan sebagai bahan pangan yang menghasilkan limbah yaitu ampas daun teh dan air cucian beras. Ampas daun teh dan air cucian beras hingga saat ini masih dimanfaatkan sebagai kompos yang dapat meningkatkan kualitas pertumbuhan tanaman hias dan pakan ternak. $^{1,2}$ Namun, masih banyak potensi yang dimiliki ampas daun teh dan air cucian beras yang dapat digunakan sebagai bahan baku kosmetik.

Ampas daun teh mengandung senyawa antioksidan yang berpotensi sebagai bahan baku kosmetik. Senyawa antioksidan tersebut adalah senyawa polifenol total, flavanoid total, asam galat, katekin dan epigallocatechin gallate (EGCG) dengan nilai masing-masing sebesar $7,1 \% ; 1,04 \%$; $2,76 \%$; $0,83 \%$; dan $5,18 \%{ }^{3}$ Selain itu, air cucian beras juga berpotensi sebagai antioksidan dan antiaging karena memiliki starch atau pati halus. Senyawa golongan karbohidrat tersebut dapat merontokkan debu dan sel kulit mati pada wajah dan dapat meregenerasi sel-sel kulit. ${ }^{4}$ Potensi air cucian beras sebagai antioksidan juga telah dilaporkan yakni adanya total polifenol sebesar 390,98 mg/100 g bahan dan daya penangkapan radikal bebas sebesar 385, 27 mmol eq.trolox/ g bahan. ${ }^{2}$ Ampas daun teh yang dilaporkan mengandung bahan antioksidan, memenuhi syarat sebagai bahan baku kosmetik dan memiliki efek sinergisme jika dikombinasikan dengan air cucian beras sebagai masker antioksidan.

Kandungan antioksidan dari ampas daun teh sebanyak $7 \%$ dan air cucian beras sebanyak 5\% yang dikombinasikan dalam formula masker gel peel-off telah dilaporkan stabil dalam penyimpanan 28 hari pada uji stabilitas sediaan dan memiliki $\mathrm{IC}_{50}$ sebesar 20,4 ppm. ${ }^{5}$ Potensi kedua ekstrak tersebut dalam sediaan masker gel peel-off diharapkan dapat memberikan efek optimal dan sinergisme untuk perawatan wajah, karena masker gel peel-off memiliki retensi yang baik, dapat mengurangi komedo dan kulit mati, serta mengurangi keriput. ${ }^{6}$ Oleh karena itu, untuk dapat digunakan sebagai perawatan wajah maka diperlukan tes keamanan kosmetika sesuai persyaratan Badan Pengawasan Obat dan Makanan (BPOM).

Tes keamanan kosmetika menurut persyaratan BPOMt ahun 2014 terdiri dari, 9 jenis, diatur dalam peraturan BPOM nomor 7 tahun 2014 tentang Pedoman Uji Toksisitas Nonklinik secara in-vivo. ${ }^{7}$ Salah satu persyaratan tes keamanan kosmetika yang akan diujikan pada formula masker gel peel-off kombinasi ampas daun teh (Camellia sinensis L.) dan air cucian beras (Oryza sativa L.) adalah uji sensitisasi dermal pada hewan uji. Uji sensitisasi dermal ini dilakukan untuk mengetahui reaksi sensitivitas pada kulit jika sediaan tersebut digunakan sebagai kosmetika perawatan wajah.

\section{METODE}

Penelitian ini merupakan penelitian eksperimental laboratorium untuk melakukan uji sensitisasi dermal terhadap sediaan masker gel peel-off kombinasi ekstrak ampas daun teh yang diekstrak menggunakan etanol dan air cucian beras secara in vivo. ${ }^{2,3}$ Hewan uji yang digunakan adalah tikus putih (Rattus norvegicus) galur Wistar dewasa muda dan sehat, berjenis kelamin jantan dengan bobot 160-300 gram menyesuiakan dengan bobot hewan uji pada BPOM RI untuk uji sensitisasi dermal.Teknik sampling untuk menentukan hewan uji menggunakan simple random sampling dengan perlakuan posttest-only control group design, dimana hewan uji dikelompokkan menjadi 3 kelompok yaitu kontrol normal (tanpa perlakuan) sebanyak 5 tikus, kontrol negatif ( $\mathrm{NaCl}$ fisiologis) sebanyak 5 tikus dan kelompok sampel (masker wajah dengan kombinasi konsentrasi $7 \%$ ekstrak ampas daun teh dan $5 \%$ endapan air cucian beras) sebanyak 10 tikus. Hewan uji tersebut kemudian 
diaklimatisasi di ruang percobaan selama 5 hari. Hewan uji dicukur bulunya 24 jam sebelum penelitian dimulai.

Penelitian ini dilakukan dalam dua tahapan uji, yaitu uji pendahuluan dan uji utama. Uji pendahuluan bertujuan untuk mengidentifikasi reaksi sensitisasi dermal yang berpotensi muncul akibat pemberian sampel uji. Uji pendahuluan dilakukan dengan melalui dua fase yaitu fase induksi intradermal dan fase uji topikal. Pada uji utama dilakukan untuk melihat respon sensitisasi dermal pada hewan uji. Uji utama dilakukan melalui tiga fase yaitu fase induksi intradermal, uji topikal dan uji tantang.

Penelitian ini telah memenuhi kaidah etik yang tertera dalam Deklarasi Helsinki 2008 sesuai dengan surat ijin Komisi Etik dan Penelitian Kedokteran FK UNSOED dengan nomor persetujuan etik Ref. 0472/KEPK/I/2018.

\section{Alat dan Bahan}

Timbangan analitik, alat-alat gelas laboratorium, stamper dan mortir, kertas saring, pinset, kompor penangas, panci, occlusive patch, elastic bandage, kassa steril, injeksi $1 \mathrm{ml}$ dan $3 \mathrm{ml}$ serta gunting.

Masker gel peel-off yang mengandung komposisi ampas daun teh, air cucian beras basis gel pembentuk peel-off (HPMC dan PVA), humektan (Propilenglikol) dan pengawet (Metil paraben dan propil paraben), Freund's Complete Adjuvant (FCA,Sigma), $\mathrm{NaCl}$ fisiologis (Otsuka), etanol $70 \%$ (Bratachem), sodium dodesilsulfat $10 \%$ (Merck), dan hewan uji tikus putih (Rattus norvegicus)

\section{Prosedur kerja}

Penelitian ini menggunakan prinsip dari metode Guinea Pig Maximization Test (GPMT) untuk menilai reaksi sensitisasi dermal terhadap kulit tikus. ${ }^{7,8}$ Tikus percobaan diaklimatisasi selama 5 harisebelum digunakan di kandang Sarana Pemeliharaan Hewan Uji Laboratorium Farmakologi dan Toksikologi Fakultas Farmasi Universitas Muhammadiyah
Purwokerto. Setiap kelompok percobaan melalui dua tahapan uji yaitu tahap uji pendahuluan dan uji utama sesuai dengan peraturan BPOM nomor 7 tahun 2014 dan ISO 10993-10. Hewan uji diberikan sampel jadi dari masker gel peel-off kombinasi ampas daun teh dan air cucian beras di area tengkuk untuk uji pendahuluan dan area punggung pada uji utama. Sampel tersebut diberikan selama 24 jam dengan dibalut oleh kassa dan perban selanjutnya ditutup dengan occlusive patch.Setelah itu, dilakukan pengamatan untuk uji pendahuluan selama 24 jam kemudian dilanjutkan ke uji utama.Pengamatan pada uji utama terhadap kulit tikusdimulai dari hari ke-0 (sebagai awal dari fase induksi intradermal), ke-1,dan ke-7 (sebagai awal fase induksi topikal). Selanjutnya, pengamatan dilanjutkan pada fase induksi topikal di hari ke-9 untuk melihat reaksi eritema dan edema. Pada fase ini sodium deodesilsufat $10 \%$ diberikan ke hewan uji jika fase induksi topikal hari ke-7 tidak terlihat reaksi eritema dan edema. Pengamatan kemudian dilanjutkan pada hari ke-11 hingga fase uji tantang di hari ke-22, ke-23, dan ke-24 dengan melakukan skoring eritema dan edema menurut skala Magnusson dan Kligman pada Tabel 1.

\section{Tabel 1.Skala Magnusson dan Kligman}

\begin{tabular}{lc}
\hline Reaksi topikal & Skor \\
\hline Tidak terlihat perubahan & 0 \\
$\begin{array}{l}\text { Eritema ringan atau bercak } \\
\text { eritema }\end{array}$ & 1 \\
$\begin{array}{l}\text { Eritema sedang atau kumpulan } \\
\text { eritema }\end{array}$ & 2 \\
$\begin{array}{l}\text { Eritema kuat dan/atau } \\
\text { edema/pembengkakan }\end{array}$ & 3 \\
\hline
\end{tabular}

\section{HASIL DAN PEMBAHASAN}

Hasil yang diperoleh dari uji pendahuluan dapat dilihat pada gambar 1 . dan tabel2. sedangkan interpretasi data skor mengacu pada Skala Magnusson dan Kligman. $^{7,8}$ 

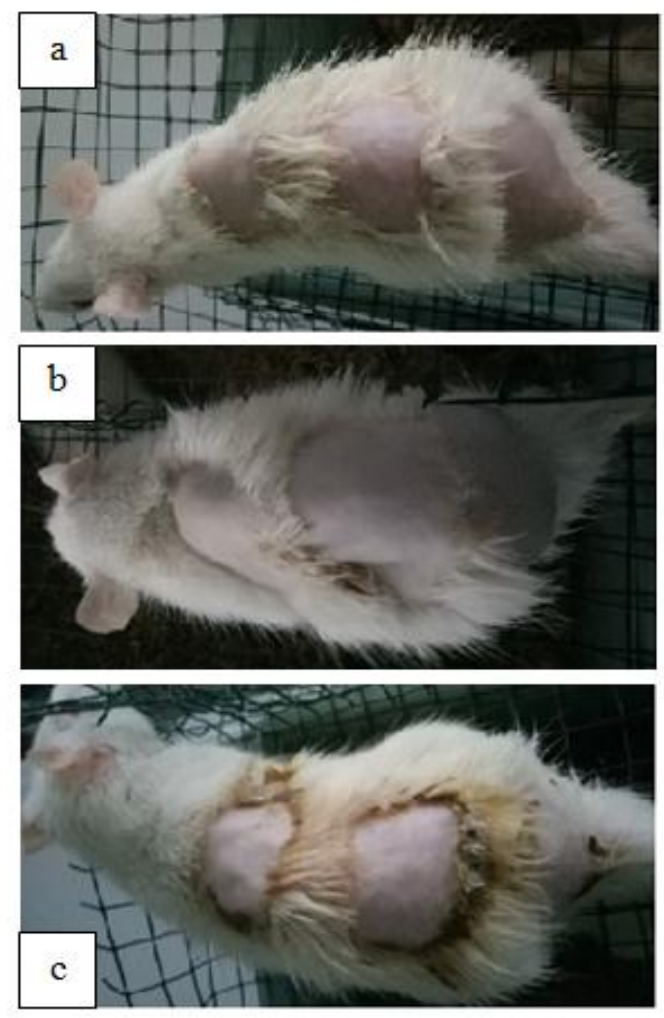

a. Kelompok normal;

b. Kelompok kontrol negatif

c. Kelompok sampel

\section{Gambar 1. Hasil Pengamatan Uji} Pendahuluan

Pada Tabel 2 menunjukkan bahwa pada semua kelompok percobaan tidak terjadi reaksi sensitisasi dermal. Hal ini dikarenakan reaksi sensitisasi membutuhkan proses untuk membentuk respon imunitas. Oleh karena itu, percobaan dilanjutkan dengan tahap uji utama untuk melihat respon sensitisasi dermal.

Hasil uji utama pada fase induksi intradermal dan uji topikal ternyata menunjukkan bahwa tidak terlihat tanda klinis eritema dan edema pada hewan uji.
Namun, setelah pengamatan induksi topikal hari ke-11 pada kelompok sampel diperoleh gambaran klinis eritema dan edema yang dapat dilihat pada gambar 2 .

Gambaran klinis eritema dan edema juga terlihat pada uji tantang (Gambar 3). Sedangkandata pengamatan uji topikal dan uji tantang dapat dilihat pada Tabel 3 . dimana interpretasi data skor mengacu pada Tabel 1.

Berdasarkan Tabel 3. tikus percobaan kelompok sampel pada hari ke-11 sebanyak 4 ekor memiliki skor 3, sebanyak 4 ekor memiliki skor 1 dan sebanyak 2 ekor memiliki skor 0. Selanjutnya, data yang diperoleh pada uji tantang untuk kelompok sampel pada hari ke-22, ke-23 dan ke-24 berturut-turut yaitu sebanyak 4 ekor memiliki skor 1 dan 6 ekor memiliki skor 0 . Interpretasi untuk skor 3 menunjukkan eritema kuat dan/atau edema (pembengkakan). Sedangkan nilai skor 1 yaitu eritema ringan atau bercak eritema serta skor 0 menunjukkan tidak ada perubahan. Data tersebut di atas menunjukkan adanya reaksi sensitisasi dermal. Reaksi sensitisasi tersebut terlihat karena antara uji induksi intradermal dan uji topikal terdapat periode masa inkubasi minimal 1 minggu dimana keadaan hipersensitivitas dapat berkembang. Dengan demikian, hasil yang diperoleh menunjukkan adanya reaksi sensitisasi pada hewan uji dibandingkan dengan kelompok normal dan kelompok negatif yang hanya diberikan $\mathrm{NaCl}$ fisiologis.

Tabel 2. Hasil pengamatan reaksi sensitisasi dermal pada uji pendahuluan

\begin{tabular}{|c|c|c|c|c|c|c|}
\hline \multirow[t]{2}{*}{ Tikus } & \multicolumn{3}{|c|}{$\begin{array}{c}\text { Hari ke-0 } \\
\text { (Induksi Intradermal) }\end{array}$} & \multicolumn{3}{|c|}{$\begin{array}{c}\text { Hari ke-1 } \\
\text { (Induksi Topikal) }\end{array}$} \\
\hline & $\mathrm{KN}$ & $\mathrm{K}(-)$ & $\mathrm{KS}$ & $\mathrm{KN}$ & $\mathrm{K}(-)$ & $\mathrm{KS}$ \\
\hline $\mathrm{T} 1$ & 0 & 0 & 0 & 0 & 0 & 0 \\
\hline $\mathrm{T} 2$ & 0 & 0 & 0 & 0 & 0 & 0 \\
\hline T3 & 0 & 0 & 0 & 0 & 0 & 0 \\
\hline \multicolumn{7}{|c|}{ Keterangan: } \\
\hline T1-T3 & Гikus p & an $1-3$ & $\mathrm{~K}(-)$ & : Kel & k neg & \\
\hline
\end{tabular}




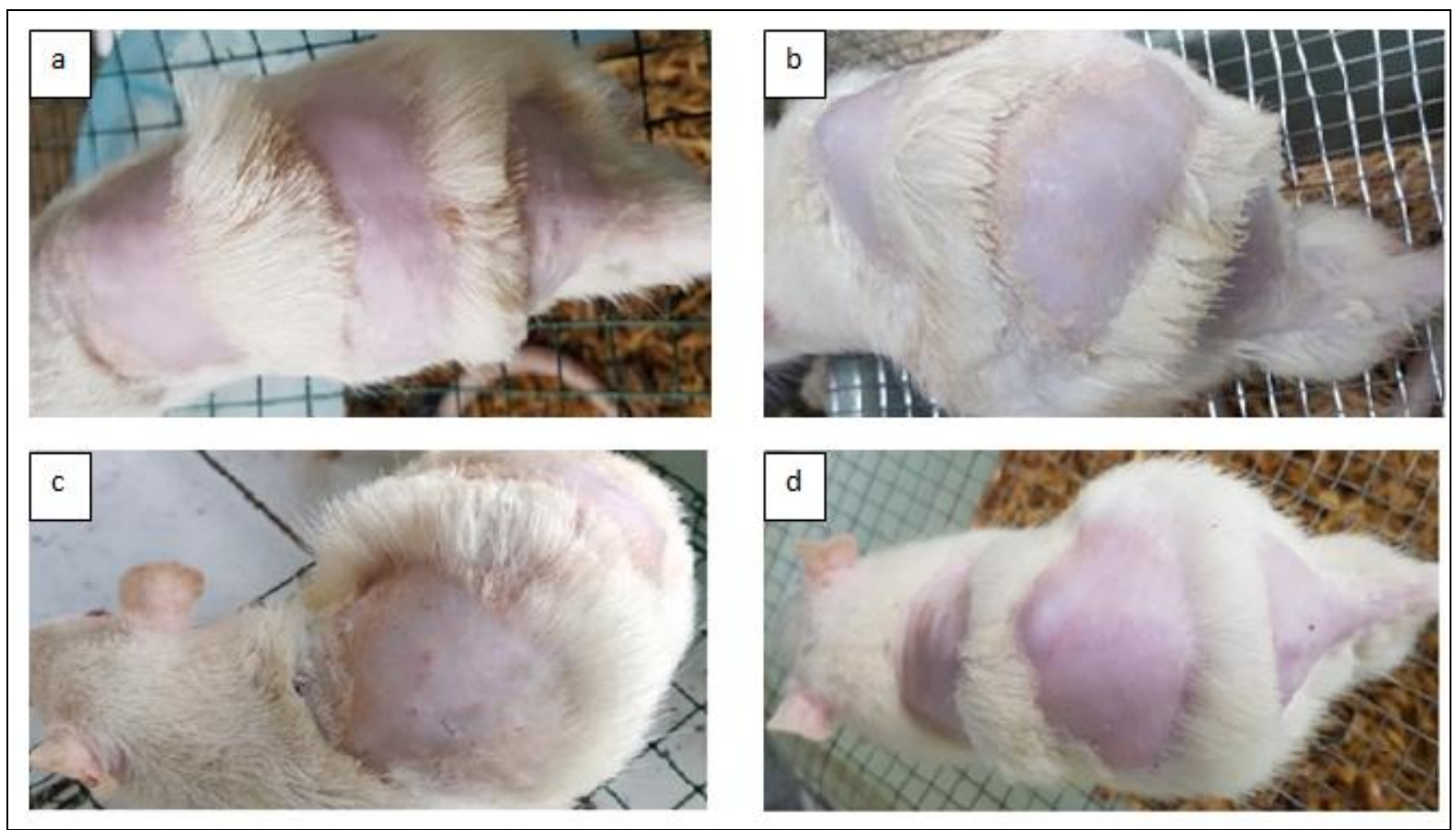

\section{Keterangan:}

a. Tikus kelompok normal

c. Tikus kelompok sampel yang mengalami berkas eritema

b. Tikus kelompok negatif

d. Tikus kelompok sampel yang mengalami edema

\section{Gambar 2. Hasil Pengamatan Uji Topikal Hari ke-1}

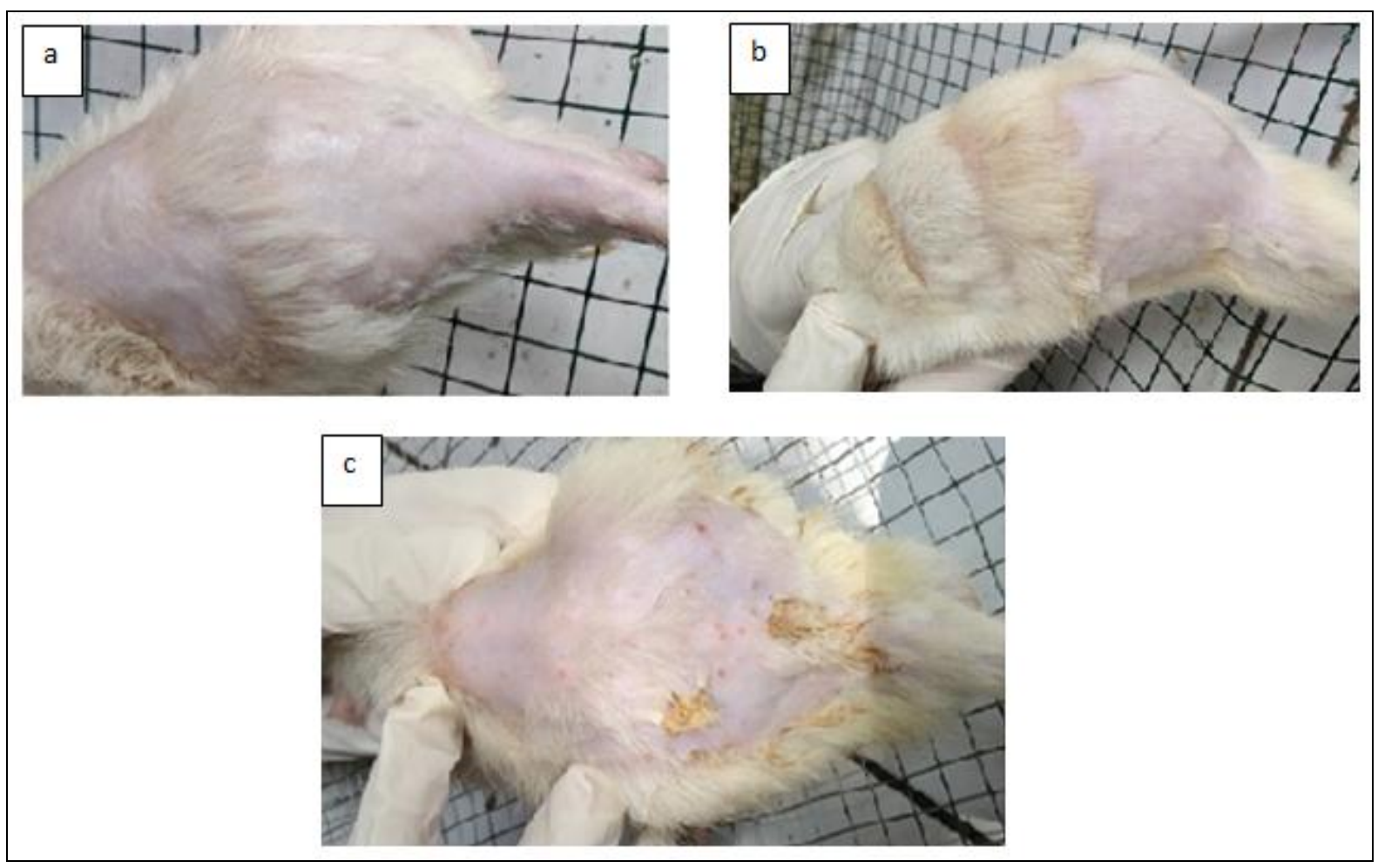

\section{Keterangan:}

a. Tikus kelompok normal

c. Tikus kelompok sampel yang mengalami berkas eritema

b. Tikus kelompok negatif

Gambar 3.Hasil Pengamatan Uji Tantang 
Tabel 3. Hasil pengamatan reaksi sensitisasi dermal pada uji utama topikal hari ke-11 sampai uji tantang hari ke-24

\begin{tabular}{|c|c|c|c|c|c|c|c|c|c|c|c|c|}
\hline \multirow{3}{*}{ Tikus } & \multirow{2}{*}{\multicolumn{3}{|c|}{$\begin{array}{c}\text { Uji Topikal } \\
\text { (Hari ke-11) }\end{array}$}} & \multicolumn{9}{|c|}{ Uji Tantang } \\
\hline & & & & \multicolumn{3}{|c|}{ Hari ke-22 } & \multicolumn{3}{|c|}{ Hari ke-23 } & \multicolumn{3}{|c|}{ Hari ke-24 } \\
\hline & KN & $\mathrm{K}(-)$ & KS & KN & $\mathrm{K}(-)$ & KS & KN & $\mathrm{K}(-)$ & KS & KN & $\mathrm{K}(-)$ & KS \\
\hline T1 & 0 & 0 & 3 & 0 & 0 & 1 & 0 & 0 & 1 & 0 & 0 & 1 \\
\hline $\mathrm{T} 2$ & 0 & 0 & 0 & 0 & 0 & 0 & 0 & 0 & 0 & 0 & 0 & 0 \\
\hline $\mathrm{T} 3$ & 0 & 0 & 1 & 0 & 0 & 1 & 0 & 0 & 1 & 0 & 0 & 1 \\
\hline $\mathrm{T} 4$ & 0 & 0 & 1 & 0 & 0 & 0 & 0 & 0 & 0 & 0 & 0 & 0 \\
\hline T5 & 0 & 0 & 1 & 0 & 0 & 0 & 0 & 0 & 0 & 0 & 0 & 0 \\
\hline T6 & $(-)$ & $(-)$ & 0 & $(-)$ & $(-)$ & 0 & $(-)$ & $(-)$ & 0 & $(-)$ & $(-)$ & 0 \\
\hline $\mathrm{T} 7$ & $(-)$ & $(-)$ & 3 & $(-)$ & $(-)$ & 1 & $(-)$ & $(-)$ & 1 & $(-)$ & $(-)$ & 1 \\
\hline $\mathrm{T} 8$ & $(-)$ & $(-)$ & 1 & $(-)$ & $(-)$ & 0 & $(-)$ & $(-)$ & 0 & $(-)$ & $(-)$ & 0 \\
\hline T9 & $(-)$ & $(-)$ & 3 & $(-)$ & $(-)$ & 1 & $(-)$ & $(-)$ & 1 & $(-)$ & $(-)$ & 1 \\
\hline $\mathrm{T} 10$ & $(-)$ & $(-)$ & 3 & $(-)$ & $(-)$ & 0 & $(-)$ & $(-)$ & 0 & $(-)$ & $(-)$ & 0 \\
\hline
\end{tabular}

Keterangan:

$\begin{array}{ll}\text { T1-T10 } & \text { : Tikus percobaan 1-10 } \\ \text { KN } & \text { : Kelompok normal } \\ \text { K (-) } & \text { : Kelompok negatif } \\ \text { KS } & \text { : Kelompok sampel } \\ \text { Skor (-) } & \text { : Tanpa T6-T10 }\end{array}$

Reaksi sensitisasi merupakan reaksi biologi kompleks yang melibatkan banyak tahap termasuk penetrasi kulit, induksi dari sinyal yang berbahaya, ikatan peptida, tahap metabolit dan aktivasi dari Antigen Presenting Cells (APC). ${ }^{9}$ Tanda dan gejala klinis pada reaksi sensitisasi dermal berupa eritema dan edema terlihat pada hewan uji kelompok sampel. Eritema dan edema timbul akibat adanya peningkatan tekanan dan bertambahnya permeabilitas pembuluh darah serta akumulasi volume cairan interstisial yang disebabkan oleh mekanisme vasodilatasi. ${ }^{10}$ Kedua gambaran klinis tersebut termasuk respon inflamasi yang timbul akibat reaksi hipersensitivitas.

Reaksi hipersensitivitas ini merupakan reaksi akibat respon sistem imum yang berlebihan pada antigen. Reaksi tersebut dikategorikan sebagai reaksi hipersensitivitas selular atau hipersensitivitas tipe IV. Reaksi ini diperantai oleh sel T CD4 ${ }^{+}$dan $\mathrm{CD} 8{ }^{+} .{ }^{11} \mathrm{Hal}$ ini dikarenakan limfosit $\mathrm{T}$ di sensitisasi khusus tanpa peran antibodi sehingga menyebabkan respon tertunda (delayed-responding). Respon hipersensitivitas tertunda dipengaruhi oleh FCA (bahan ajuvan) sebagai antigen spesifik yang membentuk respon imun melalui reaksi granulomatosa. Prosesnya ditandai dengan pembentukan granuloma berupa sel-sel berinti tunggal yang mengalami perubahan histosit, sel-sel epiteloid dan sel-sel dari benda asing. Kemudian, FCA sebagai antigen spesifik akan mengaktifkan makrofag yang khas dan memicu kepekaan limfosit $\mathrm{T}$ untuk mengeluarkan limfokin. Selain itu, adanya akumulasi neutrofil di venula daerah paparan akibat dari interaksi antar sel limfosit $\mathrm{T}$ dengan FCA, menyebabkan terlepasnya limfokin dan menarik makrofag ke daerah paparan. Aktivasi makrofag melepaskan monokin dan sitokin yaitu IL-1 dan TNF yang mengaktivasi sel limfosit untuk menghasilkan IFN- ${ }_{r}$, yang akan merangsang monosit ke jaringan sehingga meningkatkan respon inflamasi untuk menghancurkan benda asing. ${ }^{11,12}$

Benda asing yang dimaksud dalam penelitian ini adalah sodium dodesilsulfat dan masker gel peel-off kombinasi ekstrak ampas daun teh dan air cucian beras. Sodium dodesil sulfat (SDS) adalah surfaktan yang digunakan dalam formula masker gel peel-offsebagai zat aktif permukaan. SDS telah dilaporkan pada penelitian terdahulu menunjukkan hasil yang signifikan dalam menginduksi reaksi 
iritasi setelah dioleskan ke kulit dan wajah. ${ }^{13}$ Penggunaan SDS dalam pasta gigi juga dapat menghasilkan reaksi alergi dan iritasi eritematosa nonspesifik pada penggunanya. ${ }^{14}$ Hal tersebut terjadi karena SDS memicu reaksi alergi dan iritasi pada sel epitel. SDS dapat merangsang pelepasan sitokin dari sel epitel dan bertindak sebagai agen inflamasi yang menyebabkan deskuamasi mukosa mulut serta iritasi. ${ }^{15}$ Penelitian lain menunjukan bahwa reaksi iritasi kulit dapat terdeteksi hanya dengan menggunakan SDS konsentrasi rendah yang dilarutkan dalam basis gel dibandingkan basis lainnya. Hal ini dikarenakan kosmetika yang mengandung basis gel memiliki bobot molekul zat yang tinggi dan mudah larut dalam air serta menguap lebih lambat setelah kosmetik tersebut diaplikasikan. Oleh karena itu, durasi kontak antara sampel dan kulit akan lebih lama pada penggunaan gel dan dapat menyebakan reaksi iritasi yang lebih kuat dalam penggunaan aplikasi berulang. ${ }^{15}$ Selain SDS, masker gel peel-off dalam penelitian ini juga berperan sebagai benda asing.

Masker gel peel-off pada kelompok sampel hewan uji menimbulkan reaksi sensitisasi jika dibandingkan dengan hasil dari kelompok negatif yang hanya diberikan $\mathrm{NaCl}$ fisiologis dan kelompok normal. Hal ini dikarenakan efek eritema dan edema muncul setelah periode hipersensitivitas berkembang pada pemberian sampel masker gel peel-off kombinasi ekstrak ampas daun teh dan air cucian beras. Sampel tersebut dikenali oleh sistem imunitas sebagai benda asing. Pengenalan benda asing tersebut menimbulkan respon hipersensitivitas untuk menghancurkan benda asing sehingga timbul eritema dan edema pada hewan uji. Potensi SDS dan sampel masker gel peel-off sebagai benda asing tersebut yang mengaktivasi sel limfosit $\mathrm{T}$ dan monosit di dalam jaringan sehingga menyebabkan tanda kemerahan (eritema) dan pembengkakan (edema) pada kulit. ${ }^{10}$ Hasil yang didapatkan pada uji tantang selama hari ke-22, ke-23, dan ke-24 memiliki skor nilai yang sama karena ruam eritema akan mengalami proses terlepasnya stratum korneum/terkelupasnya jaringan epitel kulit (deskuamasi) dalam waktu 1-2 minggu. ${ }^{16}$

\section{KESIMPULAN}

Berdasarkan penelitian yang telah dilakukan dapat disimpulkan bahwa formula masker gel peel-off kombinasi ekstrak ampas daun teh (Camellia sinensis L.) dan air cucian beras (Oryza sativa L.) dengan bahan surfaktan SDS menimbulkan reaksi sensitisasi kulit pada hewan uji setelah pemberian pada uji utama fase uji topikal pada hari ke- 11 yang dinilai menurut Skala Magnusson dan Kligman karena kandungan SDS dilaporkan memiliki efek signifikan untuk menginduksi reaksi alergi dan iritasi.

\section{SARAN}

Perlu dilakukan uji sensitisasi kulit pada masker gel peel-off ampas daun teh (Camellia sinensis L.) dan air cucian beras (Oryza sativa L.) yang tidak mengandung SDS sebagai bahan surfaktan.

\section{UCAPAN TERIMA KASIH}

Ucapan terimakasih diberikan kepada Fakultas Farmasi Universitas Muhammadiyah Purwokerto dan Tim Uji Praklinik.

\section{DAFTAR RUJUKAN}

1. Kresno, SW. Pertumbuhan dan kualitas daun bromelia dengan menggunakan ampas teh dan air cucian beras putih. [Thesis]. Yogyakarta UPN VETERAN; 2014 http://eprints.upnyk.ac.id/10377/ diakses pada tanggal 10 Januari 20182014

2. Ijiri D, Shogo N, Kenji T, Satoru I, Akira O. Effects of feeding dried concentrated rice-washing water on growth performance and skeletal muscle lipid peroxidation in broiler chickens. Japan Poultry Science Association.2013;50:370-74 
3. Handayani D, Abdul M, Anna SR. Optimasi ekstraksi ampas teh hijau (Camellia sinensis) menggunakan metode microwave assisted extraction untuk menghasilkan ekstrak teh hijau. Traditional Medicine Journal. 2014;19(1):29-35.

4. Samahah N, Qomariyah N, Dinda DR, Eva R, Rusly H. Pengolahan air leri menjadi sabun pembersih wajah alami dan ekonomis. Prosiding Seminar Nasional Kimia FMIPA Universitas Negeri, Surabaya; 2015.

5. Annisa AN, Nisya A, Tyas AK, Maya A, Irfan N. Camorys for antiaging: Masker wajah dari limbah ampas daun teh (Camellia sinensis L.) dan air cucian beras (Oryza sativa L.). Laporan Akhir Program Kreativitas Mahasiswa Bidang Penelitian. Purwokerto: Fakultas Farmasi Universitas Muhammadiyah Purwokerto;2017.

6. Jayronia S. Design and development of peel-off mask gel formulation of tretinoin for acne vulgaris. World J. Pharm. Pharm. Sci. 2016;5:928-38.

7. Republik Indonesia. Peraturan Kepala Badan Pengawas Obat dan Makanan (BPOM) Nomor 7 Tahun 2014 tentang Pedoman uji toksisitas nonklinik secara in vivo. Jakarta: BPOM; 2014.

8. International Standard ISO 10993-10. biological evaluation of medical devices: tests for irritation and skin sensitization. ISO Third Edition. Switzerland: International Standard ISO; 2010.

9. Ball N, Stuart C, Juan CC, Hans C, Dorothea E, Roger E, et al. Evaluating the sensitization potential of surfactants: Integrating data from the local lymph node assay, guinea pig maximization test, and in vitro methods in a weight-of-evidence approach. Regulatory Toxicology and Pharmacology.2011;60(3):389-400

10. Hafizi I, Marsetyawan HNES. Penentuan konsentrasi stainless steel 316L dan kobalt kromium remanium GM-800 pada uji GPMT. Majalah Kedokteran Gigi Indonesia.2016;2(3):121-27.

11. Riwayati. Reaksi hipersensitivitas atau alergi. Jurnal Keluarga Sehat Sejahtera. 2015;13(26):22-7.

12. Zayyan AB, M. Yanuar IN, Ika KO. Pengaruh ekstrak kulit manggis (Garcinia mangostana L.) terhadap jumlah sel limfosit pada inflamasi pulpa studi in vivo pada gigi molar rahang atas tikus putih wistar jantan. Dentino Jurnal Kedokteran Gigi. 2016;1(2):140-5.

13. Marrakchi S, Maibach HI. Sodium lauryl sulfate-induced irritation in the human face: regional and age-related differences. Skin Pharmacology and Physiology. 2006;19(3): 177-80.

14. Brown RS, Langston S, Alison LG. Inflammatory reaction of the anterior dorsal tongue presumably to sodium lauryl sulfate within toothpastes: a triple case report. Oral Medicine. 2018;125(2):17-21.

15. Horita K, Daisuke H, Hiroyuki T, Mitsue Y, Akiko Y, Kayoko M. Effects of different base agents on prediction of skin irritation by sodium lauryl sulfate using patch testing and repeated application test. Toxicology. 2017;382:10-5.

16. Menaldi SLS, Prakoeswa CRS, Ayudianti P, Ramali LM, Laksono RM, Surjaatmaja $M$, et.al. Skin infections: Must known diseases. Universitas Brawijaya Press, Malang; 2016. 